\title{
Violência contra o professor nas representações sociais de docentes
}

\author{
Michelle Beltráo Soares*
}

Laêda Bezerra Machado**

\section{Resumo}

Este artigo analisa as representaçóes sociais de violência contra o professor no espaço de escolas públicas e privadas da Regiáo Metropolitana do Recife, enfatizando as formas ou tipos de violência que afetam esse grupo profissional e o modo como os docentes lidam com o fenômeno. Tomou-se como referencial a Teoria das Representaçóes Sociais, de Serge Moscovici, especialmente a Teoria do Núcleo Central, idealizada por Jean-Claude Abric. Participaram desta etapa da investigação 20 professores, sendo 10 de escolas públicas estaduais e 10 de escolas privadas. Foram realizadas entrevistas com esses professores através de pranchas indutoras, o material foi tratado a partir da Análise de Conteúdo. Os resultados do estudo indicam a dimensão prática das representaçốes desses professores, ou seja, o modo como lidam com a violência contra si no interior da escola e sala de aula, expresso através das origens da violência contra o professor, das manifestaçóes da violência contra ele e das atitudes de enfrentamento diante do fenômeno.

Palavras-chave: Violência. Professor. Representação Social.

\footnotetext{
${ }^{*}$ Mestre em Educação UFPE (2013) e Doutoranda em Educação pela Universidade Federal de Pernambuco (UFPE).

** Doutora em Educaçáo pela UFRN. Professora do Departamento de Administração Escolar e Planejamento Educacional, Centro de Educação e do Programa de Pós-Graduação em Educação na Universidade Federal de Pernambuco (UFPE).
} 


\section{Introdução}

Sem dúvida a violência constitui hoje uma das grandes preocupações da sociedade. No âmbito da escola, estampam-se cada vez mais nos jornais notícias sobre casos de agressóes sofridas por professores e alunos. O resultado dessa situação é um clima de insegurança que acomete a todos os atores do espaço escolar: professores, funcionários e alunos. O mais grave é que muitas vezes esse quadro de violência chega a se naturalizar, seja nos meios de comunicação como a televisão, seja em ambientes como a escola e as comunidades em geral, nas quais o fenômeno violência passa a ser visto como algo normal por diferentes grupos.

A escola não consegue impedir que a violência se manifeste em seu interior, ela interage em todos os sentidos com a sociedade e acaba por absorver também os fenômenos que se alastram em outras esferas sociais. Quase diariamente, diferentes meios de comunicação divulgam atos de violência cometidos dentro das escolas, essa violência não aparece apenas no plano físico, mas também psíquico e moral através do desrespeito e da violação dos direitos humanos. As agressóes físicas e verbais entre os alunos, entre professores, a invasão de "gangues", o narcotráfico, têm sido elementos presentes nas escolas, causando insegurança, medo, perplexidade e angústia aos alunos, professores, diretores e pais (ZALUAR, 1992, 2002; GONÇALVES; SPOSITO, 2002).

O professor muitas vezes é apontado como vítima da violência nos intramuros da escola, seja esta de natureza física, verbal ou simbólica. Desse modo, entende-se que várias dimensóes do cotidiano do trabalho docente estâo envolvidas com cenas de violência que trazem implicaçóes para a escola e para o trabalho nela desenvolvido. Tendo em vista essa realidade enfrentada pelos professores, os esforços na busca de compreender os aspectos da violência contra o docente culminaram em uma pesquisa desenvolvida no Mestrado em Educaçáo que analisou as representaçôes sociais de violência contra o docente, construídas por professores de escolas públicas e privadas da regiáo metropolitana do Recife-PE. O presente artigo, recorte desta pesquisa mais ampla, enfatiza essas representaçóes, as formas ou tipos de violência vivenciados pelos professores no espaço da escola e como os docentes lidam com a violência contra si.

$\mathrm{Na}$ revisão de literatura constatou-se que autores como Miriam Abramovay e Maria das Graças Rua, vêm desenvolvendo estudos significativos sobre a violência escolar no Brasil. Em pesquisa intitulada Violência nas Escolas, subsidiada pela UNESCO e publicada em formato de livro, Abramovay e Rua (2002), traçam as características da violência escolar em âmbito nacional. 
Segundo as autoras, estudos sobre o tema aparecem com mais força no Brasil a partir da década de 1980, os resultados obtidos das investigaçóes feitas nessa época apontam que as principais formas de violência na escola eram relacionadas ao crime contra o patrimônio público, como depredação e pichaçóes.

A partir dos anos 2000, percebeu-se que além dos fatores citados (violência contra o patrimônio e nas relaçóes do alunado), a violência contra o docente por parte do aluno e de pais de alunos vem tomando destaque na mídia. Não que esse tipo de violência não fosse encontrado anteriormente, mas em meados dos anos 2000 cresceram as manchetes sobre casos em que os professores estão no papel de vítima. Portanto, buscou-se com essa investigação dar vez e voz ao professor, buscando apreender como ele se situa nessa problemática partindo da sua própria ótica: as representaçóes sociais construídas a respeito da violência contra ele mesmo.

Os estudos que lançam mão da Teoria das Representaçóes Sociais, inaugurada por Serge Moscovici, buscam compreender os fenômenos construídos e revelados pelas ideias comuns expressas nas relaçóes cotidianas, o saber do senso comum. Considerou-se também que as representaçóes sociais de violência contra o professor, podem influir diretamente nas práticas docentes, portanto, optou-se por um desdobramento da grande Teoria, a abordagem estrutural (ABRIC, 1998). Diante desse contexto, é importante frisar que, para que um fenômeno se torne uma representação social, é preciso que ele seja objeto de discussão de grupos, gere estranheza ou incômodo. A violência contra o docente se acomoda nessas características e por isso é tomada como objeto de representaçáo social, uma vez que mexe com o cotidiano e a intimidade das pessoas.

O levantamento das pesquisas sobre a violência contra o professor, possibilitou destacar a lacuna existente na produção de trabalhos que versam sobre a temática. Estudos que utilizaram a violência contra o professor como objeto de pesquisa não foram localizados, assim como estudos fundamentados na Teoria das Representaçóes Sociais que tivessem, especificamente, a finalidade de compreender a violência sofrida pelos docentes. Considera-se, dessa forma, que o presente trabalho é relevante por tratar sobre uma temática de grande peso social, que é a violência contra o docente nos intramuros das escolas.

\section{A Teoria das Representações Sociais e a abordagem estrutural}

A partir do marco inaugural da Teoria das Representaçóes Sociais, a obra La Psychanalyse, son image, son public, publicada no Brasil sob o título $A$ 
Representação Social da Psicanálise, Moscovici (1961) define que a representação social é uma modalidade de conhecimento particular que tem como função a elaboração de comportamentos e a comunicação entre indivíduos. Sendo uma preparação para a ação, a representação guia os comportamentos, bem como remodela e reconstitui o ambiente em que esse comportamento tem lugar. A partir dessas considerações, podem-se constatar duas funções básicas das Representaçốes Sociais: a de estabelecer padrôes comuns de conhecimento e conduta (consenso); e a de forjar os comportamentos conforme os padróes e convençôes estabelecidos.

O sujeito não interage com o objeto social de forma neutra, como se a representação do mesmo fosse uma cópia subjetiva do real, mas sim imprime nas representaçōes deste objeto suas características, particularizando-o. É por isso que Jodelet (2001) afirma que o processo de construção das Representaçóes Sociais não se dá no vazio e sim no contexto histórico social, geográfico e cultural onde os indivíduos que representam estáo inseridos, moldando-as de acordo com seus valores, avaliando-as segundo seus filtros de julgamento e assim, guiando a conduta e orientando suas práticas. A relação entre sujeito e objeto na Teoria das Representaçôes Sociais é tão intrínseca que as Representaçôes Sociais não possuem um status definitivo, mas seu processo de construção é influenciado nas relaçóes, informaçôes e experiências do sujeito, associando e relacionando valores, imagens, conceitos, normas, crenças e símbolos.

De acordo com Wagner (1995), nas pesquisas em Representaçôes Sociais podem ser observados caminhos distintos que dependem do interesse explicativo do pesquisador e da natureza do objeto. Neste trabalho, como já indicado, seguiu-se a perspectiva teórica de Abric (1998), a Teoria do Núcleo Central ou abordagem estrutural, um desdobramento da teoria inicial das Representaçôes Sociais, de Moscovici (1978).

As representaçóes sociais possuem quatro funçóes essenciais: a função de saber, que permite compreender e explicar a realidade; a função indenitária, que define a identidade e permite a proteçáo da especificidade dos grupos; a função de orientação, guiando os comportamentos e práticas dos indivíduos; e, por fim, a função justificadora, que explica as tomadas de posição e os comportamentos (ABRIC, 1998). Essas representaçóes são elaboraçóes mentais construídas, a partir de situaçóes concretas, na dinâmica entre a atividade psíquica e o objeto representado.

O sujeito e o objeto estão sempre numa relação de construção e reconstrução de conceitos, subsidiados pelo contexto que estão inseridos. Essa 
dinâmica se expressa, principalmente, através da linguagem e é aportada no meio social dos indivíduos, portanto, fazendo parte das situaçôes reais de quem as emitem.

As representaçóes sociais, na perspectiva de Abric (1998), são formadas por dois sistemas de cogniçóes: sistema central (núcleo central) e sistema periférico. O núcleo central compreende as cogniçōes que determinam a identidade da representação, dá estabilidade e organiza seus elementos, é mais rígido e resistente a mudanças. Quando o núcleo central se modifica, modificase também toda representação. Esse núcleo há estrutura e é constituído pelas crenças, valores e normas sociais historicamente construídas e partilhadas pelo grupo. Os elementos periféricos são como esquemas de natureza mais funcional: descrevem e determinam ações. São esses elementos mais concretos, mais práticos, em ligação com os elementos centrais, que garantem que a representação social seja um guia de leitura para a realidade, relacionando-se com eventos do cotidiano dos indivíduos.

Abric (1998) assevera que toda representação funciona como um sistema de interpretação da realidade que rege as relações dos indivíduos e, orienta seus comportamentos e suas práticas sociais.

\section{Metodologia}

Como mencionado, este artigo faz parte de uma pesquisa ${ }^{1}$ mais ampla desenvolvida no curso de Mestrado em Educaçáo, realizada em duas etapas. $\mathrm{Na}$ primeira, buscou-se identificar o conteúdo e a estrutura interna das representaçóes da violência contra o docente, utilizando como instrumentos a associação livre de palavras e teste do núcleo central. A segunda etapa procurou caracterizar as formas ou tipos de violência vivenciados pelos professores no espaço da escola e indicar como os docentes lidam com esse tipo de violência, através de entrevistas estimuladas a partir de pranchas indutoras. Nos limites deste artigo, aborda-se a segunda etapa da pesquisa.

\section{Participantes}

O campo empírico para a realização desta pesquisa foram três escolas da rede pública estadual de ensino e três escolas da rede privada de ensino da regiáo metropolitana do Recife, PE. Foram selecionadas escolas de anos 
finais de ensino fundamental e ensino médio, localizadas em diferentes áreas geográficas dessa região, que deveriam atender a esse grupo de alunos, pois estudos anteriores já constataram serem predominantemente os adolescentes, os sujeitos mais envolvidos em episódios de violência contra o professor. Participaram da investigação vinte professores, dez lecionavam em escolas públicas e dez em instituições particulares. Eles foram escolhidos de maneira a considerar a variedade de faixa etária, tempo na profissão, formação acadêmica e turmas com as quais trabalhavam (de pré-adolescentes e adolescentes), e quem também já tinha participado da primeira etapa da investigaçáo.

\section{Procedimento de Coleta}

Para concretização do objetivo proposto, utilizou-se entrevistas com pranchas indutoras (Figura 1), uma variação de procedimentos projetivos. Convém dizer que o uso de instrumentos projetivos nas pesquisas em representaçóes sociais tem sido bem vindo por contribuir para a captura de discursos/conteúdos menos racionalizados por parte dos sujeitos. Assim, utilizou-se para realizaçâo das entrevistas quatro pranchas indutoras, que continham manchetes com textos e imagens a respeito da violência contra o professor, retiradas de reportagens localizadas na mídia digital. Elas foram enumeradas de 1 a 4 , a fim de facilitar a condução da entrevista.

Figura 1 - Pranchas Indutoras
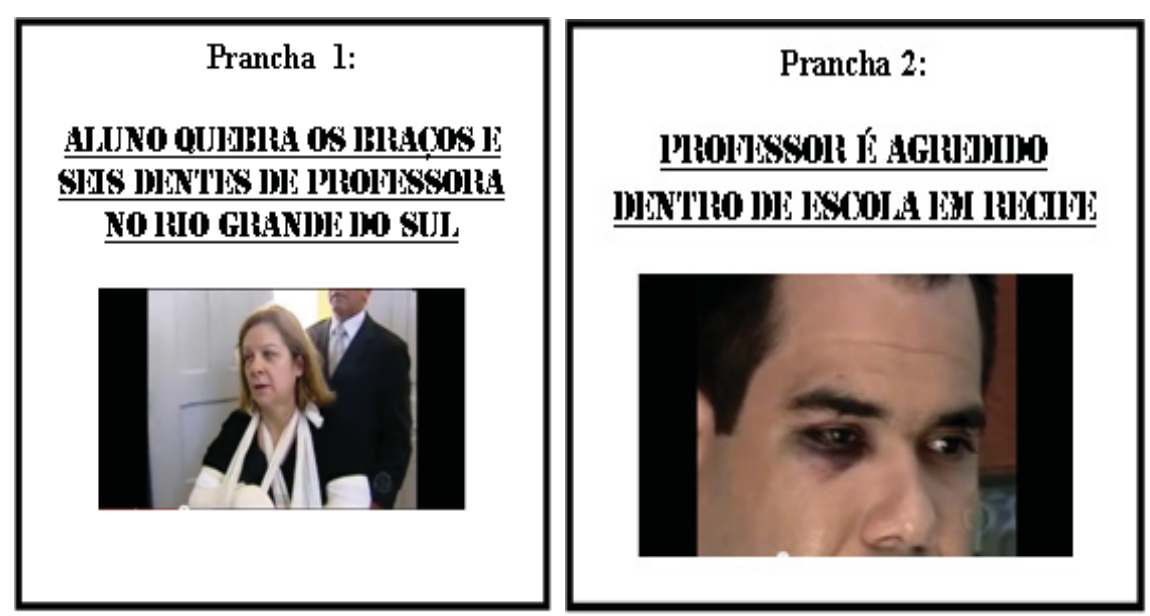

PERSPECTIVA, Florianópolis, v. 32, n. 1, 333-354, jan./abr. 2014

http://www.perspectiva.ufsc.br 


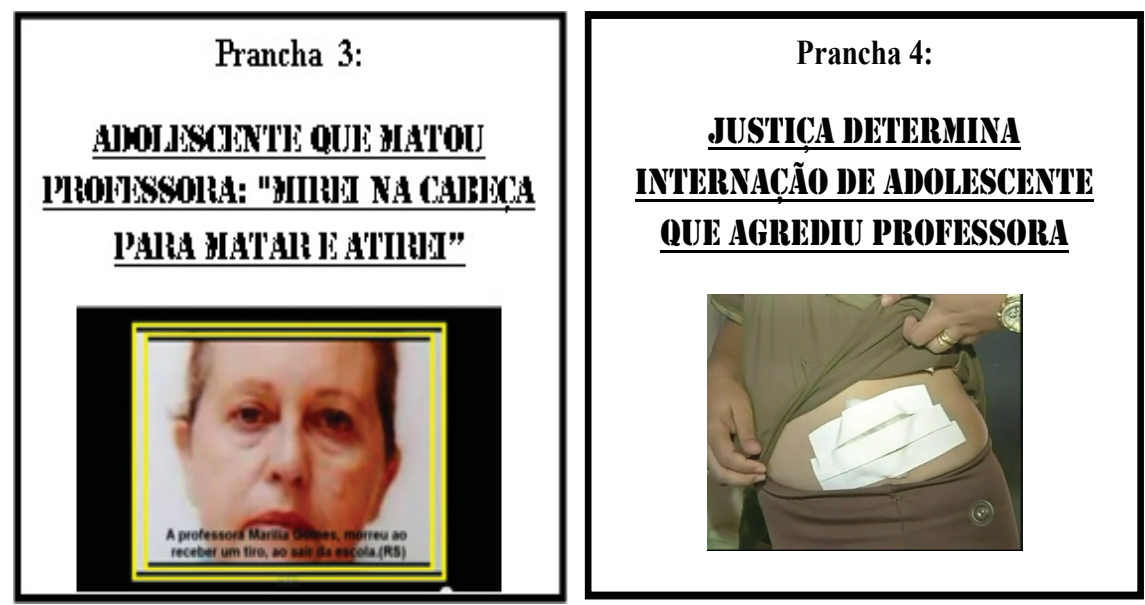

Fonte: Fontes das quais foram retiradas as figura: Prancha 1 (ALUNO..., 2010); Prancha 2: https://m. youtube.com/watch?v=eLEKBWsq3OY; Prancha 3: (ROCHA, 2010); e Prancha 4: (JUSTIÇA..., 2011).

Com a utilização desse instrumento, pretendeu-se diminuir a força da pressão de uma pergunta direta levando, possivelmente, o professor a "soltar" representaçóes sociais de modo mais tranquilo e espontâneo, acionando a partir do estímulo (manchete) os sentidos que atribui ao fenômeno da violência contra ele mesmo. Cabe dizer que o próprio Abric (2005), em ensaio sobre a zona muda das representações sociais, mostra-se favorável à construção instrumentos metodológicos menos diretos, passíveis de desvelar possíveis aspectos mascarados ou omitidos de uma dada representaçấo social.

O desenvolvimento das entrevistas se deu da seguinte maneira: apresentou-se as quatro pranchas indutoras para um professor na sequência 1 , 2, 3, 4; para o professor seguinte, apresentou-se na sequência 2, 3, 4, 1; para o próximo, na sequência 3, 4, 1, 2 e assim sucessivamente. A aplicação foi feita dessa forma a fim de evitar contaminaçóes entre uma entrevista e outra. Ao apresentar cada prancha, solicitava-se ao professor que falasse espontaneamente sobre o que via na manchete e a partir dos comentários do docente, foram feitas algumas intervençóes com o propósito de caracterizar as formas ou tipos de violência vivenciados pelos professores no espaço da escola e indicar como os docentes lidam com esse tipo de violência. Foram feitas intervenções do tipo: você já se deparou com alguma situação dessas no seu cotidiano; explicite mais esse episódio que você vivenciou; como você explica esse episódio de violência contra o professor. As entrevistas foram gravadas em áudio e posteriormente transcritas. 
Admite-se que o instrumento pranchas indutoras se adequou ao que foi pretendido neste estudo, uma vez que os participantes demonstraram descontração, interesse e desenvoltura para tratar o assunto. Lembraram-se de fatos e situaçôes que já vivenciaram por si ou por colegas de profissão e, de maneira um tanto descontraída, foram revelando os sentidos compartilhados de violência contra si, caracterizando e indicando casos, bem como evidenciando preocupação e impotência frente ao fenômeno.

\section{Procedimentos de análise}

Para o tratamento dos dados recolhidos nas entrevistas com as pranchas, utilizou-se a Análise de Conteúdo proposta por Bardin (1995). Para o autor, a análise de Conteúdo é:

Um conjunto de técnicas de análise das comunicaçóes visando obter, por procedimentos sistemáticos e objetivos de descrição do conteúdo das mensagens, indicadores (quantitativos ou nâo) que permitam a inferência de conhecimentos relativos às condiçóes de produção/recepção (variáveis inferidas) destas mensagens. (BARDIN, 1995, p. 42).

\section{Resultados e discussão}

A síntese dos depoimentos resultantes das entrevistas com os professores de instituiçóes públicas e particulares foi organizada em categorias comuns a ambos os grupos, a saber: origens da violência contra o professor; manifestaçóes de violência contra o professor; e atitudes de enfrentamento diante da violência. Elas estão articuladas e caracterizam as formas de violência vivenciadas pelos professores no espaço da escola, assim como indicam como eles lidam com a violência contra si.

\section{Origens da violência contra o professor}

A violência contra o professor compreende o caráter biopsíquico da agressividade

Em seus depoimentos, os professores distinguem duas categorias fundamentais acerca das origens da violência contra eles, uma que procura 
explicar essa violência através de um caráter biopsíquico e outra que parte do reflexo social compreendendo, principalmente, a desigualdade social e as relaçôes familiares.

Os docentes situam a perspectiva biológica através da agressividade compreendida como inerente aos indivíduos. Charlot (2002) define agressividade como uma pré-disposição biopsíquica reacional, que pode desencadear situaçōes de agressão e violência. Freud (1980), igualmente, considera a agressividade como instintiva do ser humano, o que o inclinaria a situaçóes competitivas e/ ou a cometer situaçóes de violência. Observaram-se essas questôes na fala do professor a seguir:

A gente sabe que o ser humano já tem essa caracteristica, não é? Se a gente não tivesse a agressividade, não teríamos evolução. Sem esse impulso não sairíamos do lugar, então, mesmo que esses casos sejam realmente absurdos e causem indignação, temos que ver que toda violência é formada desse fator da agressividade. Temos que fazer com que nossos alunos utilizem essa agressividade para outras coisas e não para nos agredir. (PO09EPR.EFII2).

É importante destacar que a agressividade difere da violência em si, pois essa característica biopsíquica mesmo podendo ocasionar situaçōes violentas, pode ser apropriada e utilizada como autoproteção dos indivíduos. A esse respeito, Winnicott (1987a), enfatiza a importância do ambiente para que a agressividade não se expresse em agressão. Percebe-se também que os professores dão indicativos de que as agressôes sofridas por eles são desencadeadas em parte, por essa característica biopsíquica, algo intrínseco ao ser humano que vem à tona em situaçôes de desequilíbrio emocional, que não visam necessariamente o professor:

Acredito que essa violência que a gente está vendo é como se fosse um estouro, porque a gente sabe que os adolescentes estão nessa fase de delimitar território, de contestar autoridade. Então, é como se essa condição de agressividade que já é dele, fosse extravasada dentro da sala e o professor acaba sendo um alvo, mesmo não sendo o alvo principal. (PO01EPR.EM).

A violência contra o professor, explicada a partir do fator agressividade biopsíquica, pode ser então encarada como uma manifestação de conflitos dos 
próprios alunos reeditados no ambiente escolar, em que o professor agredido não é o alvo intencional, mas sim o profissional que personifica a norma escolar, a continência apontada por Winnicott (1987a).

Para Freller (2000), os alunos agressivos na escola podem ser crianças e adolescentes que depositam suas esperanças na instituição escolar, no sentido de que ela possa suprir a necessidade de atenção ou cuidado que estes sujeitos estâo buscando, a possibilidade de expressão, o estabelecimento de limites e que nesse espaço não obtiveram respostas adequadas às suas expectativas.

Cumpre relembrar que o elemento agressão é consagrado nas representaçóes dos professores como um elemento norteador na primeira etapa da pesquisa, pertencente ao núcleo central de ambos os grupos de docente, considerado como expressão empírica da agressividade.

Portanto, essa pulsão, biológica ou psicológica, funcionaria como uma linguagem para esses alunos. Ela se manifesta em ataques rotineiros à instituição escolar, seus usuários e seus representantes (professores e funcionários), e pode ser caracterizada, na maioria das vezes, por afrontas banais e aparentemente gratuitas, como também por casos de violência extrema, deteriorando as relaçôes nesse ambiente. É dessa forma que a característica biopsíquica da agressividade ganha destaque no conteúdo geral das representaçôes sociais dos professores, em termos da violência contra eles próprios.

\section{A violência contra o professor expressa o reflexo social}

Os reflexos sociais se confirmam como os aspectos mais arraigados à representação social de violência contra o professor entre os docentes de instituiçóes públicas e privadas, sendo indiscutivelmente os elementos marcantes e norteadores dessa representaçáo social. A relação estabelecida entre violência e os eventos sociais é trazida à tona através dos reflexos da classe social a que pertencem os alunos, das comunidades em que estáo inseridos, da família da qual fazem parte e das mídias a que tem acesso.

Os espaços de pertença e as diversas relações ali estabelecidas pelos sujeitos implicariam para neles desencadear ou estimular atos violentos dentro da escola devido ao papel mais normativo e disciplinar exercido por essa instituição frente às crianças, adolescentes e jovens. Mesmo os alunos que não atribuem os valores esperados à instituição escolar, não ficam impassíveis a ela, utilizando-a como palco para a manifestação e expressão de suas frustraçôes, incluída aí a violência contra o professor. 
Ambos os grupos de professores entrevistados concordam ao assinalarem a violência contra eles como decorrência de uma desestrutura social e econômica, que gera desde a violência física até a violência simbólica. $\mathrm{Na}$ literatura, a desigualdade social também é apontada como um dos fatores que originam a violência de maneira geral. Como sinaliza Wanderley (1999), a contradição de uma sociedade desigual pode contribuir para manifestaçóes de violência física e ética.

Os participantes sugerem uma relação direta entre violência contra o professor e desigualdade social. A carência social dos alunos, na perspectiva dos entrevistados, não se vincula apenas à situação de extrema pobreza, mas às situações mais gerais de desigualdade social que provocam a exclusão. Cabe assinalar que, conforme colocaram os participantes, a desigualdade social tanto pode desencadear comportamentos agressivos para os desprovidos economicamente, quanto para os alunos de classes mais abastadas, que atribuem valores comerciais a educação escolar. Essa última afirmação é corroborada pela fala seguinte do professor da rede particular: As escolas particulares principalmente. Elas dão mais preferência ao aluno do que ao professor porque a escola hoje é um comércio muito forte, onde o professor não tem vez, o que tem vez é o cliente que é o aluno que paga. (PO03EPR.EFII).

A violência simbólica para os professores da escola pública se expressa através das relaçóes de desigualdades socio-econômicas e se enquadra na definição original proposta por Bourdieu e Passeron (1975), assim como no sentido da violência estrutural proposta por Minayo (1999). Para a autora, trata-se da "violência gerada por estruturas organizadas e institucionalizadas, naturalizada e oculta em estruturas sociais, que se expressa na injustiça e na exploração e que conduz à opressão dos indivíduos" (MINAYO, 1999, p. 8).

Por outro lado, a violência simbólica para os docentes da rede particular vincula-se às relaçóes de assédio moral tanto por parte dos alunos, pertencentes a uma classe econômica privilegiada, quanto por parte das instituiçóes de ensino. Portanto, assume-se, uma semelhança entre o processo de reprodução da cultura dominante sobre as camadas populares na escola e o vivido pelos professores, como intelectuais que estáo vendendo sua força de trabalho a particulares (donos de capital).

Além da desigualdade social, outro aspecto que se manifestou nos depoimentos dos professores foram as implicaçōes da estrutura familiar dos alunos para a incidência de violência contra os docentes. A falta de sintonia entre 
escola e família, no que se refere ao papel de ambas as instituiçōes, concorre para o professor avaliar suas atitudes e a própria profissão (FALSARELLA, 2008; NOGUEIRA, 2005).

Outra questáo enfatizada nas falas dos professores foi o papel da mídia como propulsora da violência contra o professor. A mídia, principalmente a televisiva, com a exposição excessiva e banalizada de casos violentos pode influenciar para que os alunos constituam novas e negativas interpretaçōes da violência (MARTÍN-BARBERO, 2000). Para Njaine e Minayo (2003, p. 127), a banalização da violência, bem como a transmissão de exemplos inadequados por parte da mídia, "promove uma certa confusão de perspectiva sobre o real e o imaginário e, por consequência, uma banalização das relaçôes sociais fundadas nas agressóes e na eliminação do outro".

Portanto, os professores sugerem que os eventos de natureza social se configuram como aspectos norteadores das representaçóes, no que concerne ao desencadeamento da violência contra o professor. Podem ser expressos através da desigualdade social e política, constituída como um reflexo da sociedade atual (crise de valores, crise civilizatória) e através das implicações da influência familiar, tanto por meio da mercantilização da educação quanto mediante a aparente negligência para com o papel educador inerente à instituição familiar. Esses achados corroboram os estudos que vêm mostrando que as raízes da violência na escola encontram-se na violência social, na família e em condiçóes estruturais como a pobreza e a desigualdade social (LUCINDA; NASCIMENTO; CANDAU, 1999; GUIMARÃES, 1996).

\section{Manifestações de violência contra o professor}

Através das entrevistas foi possível compreender o que o professor, no cotidiano de suas práticas e relaçôes, considera como manifestaçóes de violência contra ele. São tomadas como amostras empíricas de violência contra o professor, por eles próprios, a violência verbal e indireta, física e a depredação do ambiente escolar. Do ponto de vista das características, os professores de escolas públicas enfatizaram as experiências de agressóes físicas e depredaçôes; os das instituiçôes particulares deram destaque às humilhações e agressōes verbais. Isso reforça a consideração feita por Moscovici (1978) de que as representaçôes sociais se referem a construções simbólicas que reúnem experiências elaboradas em contextos diversos. 
Constatou-se que a violência verbal foi a mais sofrida e enfrentada pelos docentes tanto de escolas públicas quanto de escolas particulares. Essa violência aparece como o tipo mais comum e corriqueiro. Conforme Debarbieux (2006), Charlot (2002) e Abramovay (2005), em alguns estabelecimentos escolares as incivilidades estáo incorporadas em comportamentos cotidianos, em que alunos e professores são profundamente atingidos no que diz respeito à identidade profissional, pessoal e dignidade. Estas ações de incivilidades são muitas vezes entendidas como violência.

O que é considerado corriqueiro, o que se torna banalizado, pode ocasionar sensação de impotência, de conformismo. E mais grave ainda, a violência banalizada pode ser naturalizada em algumas situaçóes nas relaçóes interpessoais na escola, o que é corroborado pela afirmação de Abramovay e Rua (2002, p. 236) transcrita a seguir:

Em um primeiro momento, essas ocorrências menos severas como xingamentos, desaforos ou agressóes verbais em geral são pensadas mais como precursores de ocorrências graves, do que como práticas violentas em si. Quando se limitam ao enfrentamento verbal podem se resolver pelo diálogo e negociação. Em outros casos, mesmo começando com troca de ameaças, desaforos, ofensas ou provocaçôes, agravem-se até chegar às agressōes físicas, que requerem, muitas vezes, o envolvimento da política.

Esse agravamento da situação, demonstrado através da agressão física, é trazido à tona na representação dos docentes de ambas as redes, porém com perspectivas diferentes. Os professores da rede pública relatam casos de violência física que presenciaram, tiveram contato próximo ou vivenciaram. Os professores da rede particular, por sua vez, citam casos de violência física que ocorreram ou que tomaram conhecimento sofridos por colegas, preferencialmente, vinculados à rede pública. Afirmaram os participantes:

Já teve um caso de um amigo meu que o aluno disse pra ele "olhe está vendo professor, com esse saco aqui de maconha eu ganho muito mais dinheiro do que o senhor ganha em um mês, eu vendo ele em dois, três dias e já ganho o seu salário que o senhor ganhou o mês inteiro". Então você vê 
que a realidade é bem diferente, né? Ai nesse caso esse é um amigo meu que trabalha na rede pública. (PA07EPR.EFII).

Comigo já aconteceu o aluno queria bater em mim porque eu quis que ele fizesse o trabalho. Segundo ano médio, no ano retrasado. Um aluno grande! Quase que era como a primeira professora, com os dentes quebrados. (PA02EPU.EM).

Como observado, o discurso dos professores de escolas privadas, frequentadas por alunos das classes mais abastadas, aponta que em estabelecimentos escolares públicos, onde os alunos são mais vulneráveis à desigualdade social, podem existir mais e mais graves situaçôes de violência contra o professor.

Convém destacar que, mesmo assinalando algumas situações que envolvem violência contra o professor (violência institucional e violência verbal), a fala dos docentes da rede privada no que concerne à violência física, remete a um expectador, alguém que representa a violência a partir do outro, neste caso, de seus pares (docentes da rede privada). Já o professor da escola pública fala mais abertamente do que ele vivencia, demonstrando propriedade do objeto, inclusive nos casos de agressões físicas. São dois grupos com bases de representaçóes diferentes da violência física contra os docentes: enquanto os professores da rede pública representam a violência baseados em situações reais de enfrentamento, os professores da rede privada representam essa violência a partir de outros referentes, como as conversas, os episódios vivenciados por colegas de profissão e o que circula sobre o assunto nas redes sociais.

Através dessa prerrogativa, pode-se inferir que estamos diante de uma zona muda na representação dos docentes das escolas privadas. Se o referente empírico da violência se configura justamente como a violência física (MICHAUD, 1989), a narrativa de negativa perante casos desse tipo sugere que a violência contra o docente não se concretiza de fato nas escolas privadas, restringindose à esfera simbólica. Desse modo, dois aspectos parecem estar compondo a representação dos docentes de escolas privadas: um verbalizado, explícito (a violência institucional e indireta), outro não explicitado, que, conforme Abric (2005), incidiria numa zona muda da representação. Essa zona muda incluiria os aspectos racionalizados pelos indivíduos que podem ser expressáveis, de acordo com a normatividade da situação em que se encontram. É o "politicamente correto" que comumente se fala, é uma tentativa do sujeito de aceitação social. 


\section{Atitudes de enfrentamento diante da violência}

$\mathrm{Na}$ tentativa de identificar práticas docentes frente à violência contra o professor no contexto da escola, procuramos captar dos sujeitos entrevistados suas açôes para o enfrentamento desse fenômeno. $\mathrm{O}$ que se captou foram mais sugestôes do que açóes. Essas sugestôes para prevenir a violência contra o docente demonstraram um leque de possibilidades que se expressa através do dinamismo e da complexidade desse tipo de violência. Os professores tendem a sugerir açóes contra essa violência de maneira geral e não as concretizarem de fato. No campo da efetivação, encontram-se a tentativa de manter um bom relacionamento com os alunos e a punição dos agressores através da expulsão da sala de aula, conversas com os pais e até mesmo repressão policial.

Os professores concordam que a falta de medidas punitivas concorre para propagação da violência, tanto no ambiente escolar como também na sociedade como um todo. Eles aderem à ideia de extrair ou retirar do ambiente escolar, ou da sociedade (dependendo do ato violento praticado), o aluno que esteja cometendo atos agressivos, pois o sentimento de impunidade pode gerar manifestaçôes mais graves de violência para com o professor:

Apesar de se compreender os graves aspectos criminosos apontados pelos professores, os próprios docentes revelaram que a violência contra eles decorre principalmente de uma estrutura social dominante, que funciona como princípio gerador e explicativo da violência contra o professor e supera a prerrogativa da responsabilização apenas do indivíduo. As alternativas de acolhimento do jovem e o diálogo, melhoraria do ambiente escolar e até mesmo da melhora dos laços de convivência para combater essa violência estão presentes nas sugestóes dos professores.

Essas alternativas se expressam na tentativa de estabelecerem um bom relacionamento com os alunos, bem como desenvolver projetos pedagógicos para enfrentar os diversos tipos de violência na escola, não apenas a violência contra o docente. Os educadores deram pistas de que deveriam discutir junto com a comunidade escolar sobre sua exposiçáo à violência, buscando juntos formas de prevenção, pois muitos não se sentem preparados para desenvolver estratégias de enfrentamento para a violência contra ele mesmo.

De acordo com Gilly (2001), a representação articula de modo coerente as controvérsias entre a realidade e a ideologia, assegurando a função de legitimação do sistema da representação e de justificação das práticas cotidianas (LIMA, 
2009). Pode-se inferir a partir disso, que a representação dos docentes revela contraditoriedade entre o que se espera (as sugestóes dadas por eles) e o que realmente se exercita no cotidiano de suas práticas.

Outra questão levantada pelos professores é a relação da família com a escola na resolução de conflitos. Para Njaine e Minayo (2003) a integração da família e a escola permite uma efetiva parceria na prevenção da violência na escola. Os professores também apontam essa integração, reconhecendo-a como um dos pontos fundamentais no combate à violência no ambiente escolar. O elo família-escola permitiria ampliar o diálogo sobre o fenômeno da violência, amparado pela escola e família do aluno, contribuindo para diminuir as distâncias nas relaçóes professor, aluno e família, na tentativa de reverter comportamentos agressivos de alguns alunos.

\section{Considerações Finais}

Os resultados da investigação indicaram que a violência contra o professor envolve elementos de diferentes ordens, sendo comportamentais, psicológicas, afetivas, entre outras. A segunda etapa da pesquisa apresentada neste artigo, contribuiu para o aprofundamento e elucidação de questốes apreendidas no levantamento da estrutura e do conteúdo das representaçóes na primeira etapa do estudo. Enquanto a representação dos professores da rede privada norteiase pelo elemento institucional, que expressa na prática docente uma violência predominantemente simbólica e indireta (assédio moral, subserviência etc.); a representaçáo dos professores de escola pública considera elementos sociais (família, desigualdade social etc.) como fatores geradores e explicativos da violência contra eles na sala de aula, indicando que a violência contra o professor é um reflexo de uma sociedade desigual, que violenta o aluno e faz dele um reflexo da mesma na sala de aula.

Os achados gerais do trabalho, apesar de não situarem as situaçóes pedagógicas como espaços de geração da violência contra o professor, revelaram uma tendência dos docentes a relacionarem a violência contra eles como fenômeno passível de ser combatido por meio de situaçóes pedagógicas. Portanto, além de questôes de cunho social, o fenômeno está relacionado a questóes de ordem pedagógica. Mais do que estabelecer uma relação entre pobreza e violência, os professores parecem indicar que a relação direta se dá entre violência e desigualdade social. 
Cumpre ainda ressaltar que a ênfase dada pela abordagem estrutural à função prática das representaçóes advém do entendimento de que as representaçóes determinam os comportamentos dos sujeitos e dos grupos. Pode-se admitir que o presente estudo permitiu captar a dimensão prática das representaçóes desses professores, ou seja, o modo como lidam com a violência contra si no interior da escola e sala de aula, expresso através das origens da violência contra o professor, das manifestaçóes da violência contra ele e das atitudes de enfrentamento diante do fenômeno.

Tendo em vista seus depoimentos, as representações dos docentes vão orientar açôes de combate à violência contra si que serão peculiares às especificidades de cada instituição. Dessa forma, as especificidades das instituiçôes escolares e a natureza dos atos violentos predominante nas relaçôes interpessoais nas escolas, demandam por estratégias de enfrentamento que considerem as características sociais, econômicas e culturais da populaçáo em que a escola se encontra. $\mathrm{O}$ envolvimento de professores, funcionários, pais e alunos, também foi indicado como de fundamental importância para dirimir a violência contra o professor visto a complexidade e a dinâmica do fenômeno em questão.

\section{Nota}

${ }^{1}$ Pesquisa financiada pela FACEPE.

${ }^{2} \mathrm{~A}$ caracterização dos professores se refere: PO (Professor); PA (Professora); 01 (respondeu a entrevista no 01); EPR (Escola Privada); EPU (Escola Pública); EM (Ensino Médio); EFII (Ensino Fundamental II).

\section{REFERÊNCIAS}

ABRAMOVAY, Miriam (Org.) Cotidiano das escolas: entre violências. Brasília: UNESCO; MEC, 2005.

ABRAMOVAY, Miriam; RUA, Maria das Graças. Violências nas Escolas. Brasília, DF: UNESCO, 2002.

ABRIC, Jean-Claude. A abordagem estrutural das representaçóes sociais. In: MOREIRA, Antônia Silva Paredes; OLIVEIRA, Denize C ristina de (Org.). Estudos interdisciplinares de Representação Social. Goiânia: AB, 1998. p. 27-38. 
ABRIC, Jean Claude. A zona muda das representaçóes sociais. In: OLIVEIRA, Denize Cristina de; CAMPOS, Pedro Humbero. Representaçôes Sociais, uma teoria sem fronteiras. Rio de janeiro. Museu da República. 2005. p. 22-34.

ALUNO quebra os braços e 6 dentes de professora no RS. G1, Porto Alegre, 12 nov. 2010. Disponível em: <http://g1.globo.com/brasil/noticia/2010/11/ aluno-quebra-os-bracos-e-6-dentes-de-professora-no-rs.html> .

BARDIN, Laurence. Análise de conteúdo. Lisboa: Ediçóes 70, 1995.

BOURDIEU, Pierre, PASSERON, Jean-Claude. A reprodução: elementos para uma teoria do sistema de ensino. Rio de Janeiro: Francisco Alves, 1975.

CHARLOT, Bernard. Da relação com o saber: elementos para uma teoria. Porto Alegre: Artmed, 2002.

DEBARBIEUX, Eric. Violência na Escola. Lisboa: Instituto Piaget, 2006.

FALSARELLA, Ana Maria. E a família, como vai? Presença Pedagógica, São Paulo, v. 14. n. 84, nov./dez., 2008.

FRELLER, Cintia Copit. Trabalhando com pais sobre indisciplina escolar: um desafio para o psicólogo. In: ASSOCIAÇÃO NACIONAL DE PÓSGRADUAÇÃO E PESQUISA EM EDUCAÇÃO, 23., Caxambu, 2000, Anais... Caxambu, MG: ANPEd, 2000. Disponível em: <http://23reuniao. anped.org.br/textos/2001t.PDF $>$. Acesso em: 23 abr. 2012

FREUD, Sigmund. A dinâmica da transferência. In: FREUD, Sigmund Standard edition da obra psicológica completa de Sigmund Freud. Rio de Janeiro: Imago, 1980. p. 133-143. 12 v.

GILLY, Michel. As representaçóes sociais no campo da educação. Im: JODELET, Denise (Org.). As representaçôes Sociais. Rio de Janeiro: EDUERJ, 2001. p. 321- 341.

GONÇALVES, Luiz Alberto; SPOSITO, Marília Pontes. Iniciativas públicas de redução da violência escolar no Brasil. Cadernos Pesquisa, São Paulo, n. 115, p. 101-138, mar. 2002.

GUIMARÃES, Maria Eloísa. Escola, galeras e narcotráfico. 1996. 205f. Tese (Doutorado em Educação) - Pontifícia Universidade Católica do Rio de Janeiro, Rio de Janeiro, 1996. 
JODELET, Denise. Representaçōes sociais: um domínio em expansão. In: JODELET, Denise (Org.) Representaçôes Sociais. Rio de Janeiro: EDUERJ, 2001. p. 17-44.

JUSTIÇA determina internação de adolescente que agrediu professora. G1, São Paulo, 16 mar. 2011. Disponível em: <http://g1.globo.com/sao-paulo/ noticia/2011/03/justica-determina-internacao-de-adolescente-que-agrediuprofessora.html>.

LIMA, Andreza Maria de. O bom aluno nas representaçóes sociais de professoras da Rede Municipal do Recife. 2009. Dissertação (Mestrado em Educação) Universidade Federal de Pernambuco, Recife, 2009.

LUCINDA, Maria da Consolação; NASCIMENTO, Maria das Graças; CANDAU, Vera Maria. Escola e violência. Rio de Janeiro: DP\&A, 1999.

MARTIN-BARBEIRO, Jesus. Comunicação e mediaçôes culturais. Revista Brasileira de Ciências da Comunicação, São Paulo, v. 23, n. 1, jan./jun. 2000.

MINAYO, Maria Cecília de Souza. O desafio do conhecimento: pesquisa qualitativa em saúde. 6. ed. São Paulo: Hucitec, 1999.

MICHAUD, Yves. A Violência. São Paulo: Ática, 1989.

MOSCOVICI, Serge. A Representação Social da Psicanálise. Tradução de Álvaro Cabral. Rio de Janeiro: Zahar, 1978.

NJAINE, Kathie; MINAYO, Maria Cecília de Souza. Violência na escola: identificando pistas para a prevenção. Interface: comunicação, saúde e educação, Botucatu, SP, v. 7, n. 13, p. 119-134, ago. 2003.

NOGUEIRA, Maria Alice. Família e escola na contemporaneidade: os meandros de uma relação. In: ASSOCIAÇÃO NACIONAL DE PÓSGRADUAÇÃO E PESQUISA EM EDUCAÇÃO, 28., Caxambu, 2005, Anais... Caxambu, MG: ANPEd, 2005.

ROCHA, Carolina. Adolescente que matou professora: "mirei na cabeça para matar e atirei”. Diário Gaúcho, Porto Alegre, 30 jun. 2010. Disponível em: <http://diariogaucho.clicrbs.com.br/rs/noticia/2010/06/adolescenteque-matou-professora-mirei-na-cabeca-para-matar-e-atirei-2955292.html>. 
WAGNER, W. Descrição, explicação e método em pesquisa das Representaçôes Sociais. In: - GUARESCHI, P; JOVCHELOVITCH, S.

(Orgs); Texto em Representações Sociais 2a ed. - Petrópolis/RJ: Vozes, 1995. p.149-185.

WANDERLEY, Mariangela Belfiore. Refletindo sobre a noção de exclusão. In: SAWAIA, Bader (Org.) As artimanhas da exclusão: análise psicossocial e ética da desigualdade social. Petrópolis, RJ: Vozes, 1999.

WINNICOTT, Donald W. Agressão. In: Privação e Delinquência São Paulo: Martins Fontes. 1987. p. 89-96.

ZALUAR, Alba (Org.). Violência e educação. São Paulo: Cortez editora, 1992.

ZALUAR, Alba. Máquina e Revolta. 2. ed. São Paulo: Brasiliense, 2002.

Violencia contra el profesor en las representaciones sociales de los maestros 


\section{Violencia contra el profe- sor en las representaciones sociales de los maestros}

\section{Resumen}

Este artículo analiza las representaciones sociales de la violencia en contra del maestro en las escuelas públicas y privadas de la Región Metropolitana de Recife (RMR), Brasil, haciendo hincapié en las formas o tipos de violencia que afectan a este grupo de profesionales y el modo de cómo los profesores actúan frente a este fenómeno. Para tal fin, se trabajó con referencia de la Teoría de las Representaciones Sociales de S. Moscovici, especialmente la Teoría Núcleo Central, creada por JC Abric. Participaron en esta fase de la investigación 20 profesores, 10 escuelas públicas y 10 escuelas privadas. Se realizaron entrevistas con los profesores a través de estos consejos inductores. Las entrevistas fueron examinadas a partir del Análisis de Contenido. Los resultados del estudio indican la dimensión práctica de las representaciones de los profesores, es decir, cómo hacer frente a la violencia contra sí mismos dentro de la escuela y del aula, expresada a través de los orígenes de la violencia en contra del maestro, las manifestaciones de la violencia en su contra y las actitudes de enfrentamiento delante del fenómeno.

Palabras claves: Violencia. Profesor. Representación Social.

\section{Violence against professor in teachers social representations}

\begin{abstract}
This article analyzes the social representations of violence against the teacher within public and private schools in the Metropolitan Region of Recife (RMR), emphasizing the forms or types of violence affecting this professional group and how teachers deal with the phenomenon. The Theory of Social Representations of S. Moscovici, especially the Central Nucleus Theory, created by JC Abric were taken as a reference. 20 teachers (10 public schools and 10 private schools) participated in this phase of investigation. Interviews were conducted with teachers by inducing boards. The interview material was treated from the content analysis. The study results indicate the practical dimension of the representations of these teachers, ie, how to deal with violence against themselves inside the school and classroom, expressed through the origins of violence against the teacher, the manifestations of violence against him and coping attitudes concerning the phenomenon.
\end{abstract}

Keywords: Violence. Professor. Social Representations. 


\section{Michelle Beltráo Soares}

E-mail:michellinha7@gmail.com

Laêda Bezerra Machado

E-mail:laeda01@gmail.com

Recebido em: 18/4/2013

Versáo final recebida em: 11/10/2013

Aprovado em: 15/10/2013 